\title{
Molecular Characterization and Sequence Analysis of iNOS Gene of Guinea Fowl (Numida meleagris)
}

\author{
G. Goyal $^{1,2 *}$, R. K. S. Bais ${ }^{2}$, V. Upmanyu ${ }^{3}$, V. Agrawal $^{1}$, K. Shrman ${ }^{1}$, \\ A. K. Patil ${ }^{1}$ and Y. A. Chatur ${ }^{1}$ \\ ${ }^{I}$ Nanaji Deshmukh Veterinary Science University, Jabalpur, M.P., India \\ ${ }^{2}$ Central Avian Research Institute, ${ }^{3}$ Indian Veterinary Research Institute, \\ Izatnagar, Bareilly, U.P., India \\ *Corresponding author
}

\section{A B S T R A C T}

\begin{tabular}{|l|}
\hline Key w or d s \\
$\begin{array}{l}\text { Guinea fowl, iNOS, } \\
\text { Nucleotide } \\
\text { sequence, Genetic } \\
\text { similarity and } \\
\text { variability }\end{array}$ \\
\hline Article Info \\
\hline $\begin{array}{l}\text { Accepted: } \\
\text { 20 December } 2020 \\
\text { Available Online: } \\
\text { 10January 2021 }\end{array}$ \\
\hline
\end{tabular}

A792 bp fragment of iNOS gene in guinea fowl has been successfully amplified using the primers designed from available sequence of iNOS gene of chicken. This fragment is equivalent to the chicken iNOS in size and no insertion or deletion was observed. Sizable polymorphism was observed between guinea fowl and other poultry species for iNOS nucleotide sequence. The ratio between non-synonymous to synonymous nucleotide substitutions was 1:4.6 between guinea fowl and chicken, whereas it was 1:4.3 between guinea fowl and quail. The iNOS amino acid sequence comprised of 263 amino acids in guinea fowl. The nucleotide sequence alignment of Gf-iNOS gene with the iNOS genes from other poultry species identified 7 SNPs i.e. T/A, C/T, T/C, A/T, G/A, G/A and C/T substitution at 320, 370, 409, 460, 484, 520 and 553 nt positions, respectively in our GfiNOS sequence. For Gf-iNOS PCR-RFLP, Mbo I, Sau3A I, Nde II and Dpn I were identified. Similarly, for PCR-RFLP of chicken iNOS, Rsa I, Eco47 III and Hae II; and for quail iNOS, Mn II, Hpa II, Nci I, Msp I and Nsi I were identified.Based on nucleotide sequence comparisons for iNOS gene, guinea fowl showed very high and almost equal per cent identity (95.6 - 96.2) with chicken and quail. Quail and chicken also showed very high per cent identity (96.7-97.0) between them. phylogenetic analysis also revealed the similar trend. The polymorphism identified in iNOS CDS in present study, may be utilized for exploring the mechanism of higher disease resistance in guinea fowl, which may further be exploited to develop disease resistant chicken population.

\section{Introduction}

Nitric oxide synthase (NOS) are group of enzymes that catalyze the production of nitric oxide (NO). Nitric oxide is a short-living molecule having a half-life of few seconds and capable of diffusing across membranes and reacting with a variety of targets. Nitric oxide synthase is involved in production of NO and L-Citruline from L-Arginine. Mammalian and avian systems have three well-characterized isoforms of NOS, two constitutive forms viz. neuronal NOS (nNOS, also called as NOS-1), endothelial NOS 
(eNOS or NOS-3), and an inducible form viz inducible NOS (iNOS or NOS-2). All isoforms utilize the amino acid arginine, molecular oxygen, and NADPH as substrates and require tetra-hydrobiopterin, FAD, and FMN as cofactors (Marletta, 1993). The two constitutive forms are activated by and dependent on changes in intracellular calcium (Nathan, 1992), whereas the inducible isoform is calcium independent apparently because calmodulin is a tightly bound subunit of the iNOS (Cho et al., 1992).

Inducible Nitric Oxide Synthase produces $\mathrm{NO}$, an important mediator in non-specific immunity with various microbicidal activities against broad spectrum of protozoa, fungi, bacteria and viruses (Liew et al., 1990). De Groote \& Fang (1995) reported that the NO inhibits the growth of many bacteria and parasites in vitro.

First non-mammalian iNOS cDNA was characterized from chicken macrophage which was approximately $4.5 \mathrm{~kb}$ mRNA, encoding 1,136 amino acid open reading frame and $130 \mathrm{kDa}$ protein (Lin et al.,1996).The deduced chicken macrophage NOS protein sequence showed $66.6 \%$ (79.1\%), $70.4 \%$ (81.2\%), 54.2\% (71.7\%) and $48.7 \%(66.1 \%)$ sequence identity (similarity) to mouse iNOS ((Lyons et al., 1992 \& Xie et al., 1992), human iNOS (Charles et al., 1993), rat brain cNOS (Bredt et al., 1991) and bovine endothelium cNOS (Lamas et al., 1992), respectively.

Guinea fowl, an important poultry species comes under family Numidae under order galliformes. Guinea fowl differs from the fowl not only in their phenotypic appearance but also in behavioral and production characteristics. One very important characteristic of guinea fowl is its resistance to the common diseases occurring in chicken, which make guinea fowl an important model to study the mechanism of disease resistance. Since iNOS gene through nitric oxide production have noteworthy and concerted role in immune response against pathogens, characterization of the iNOS gene in guinea fowl may provide significant information for better understanding of the mechanism of disease resistance in poultry. The present investigation was mainly aimed to clone and sequence the cDNA of iNOS gene of the guinea fowl.

\section{Materials and Methods}

\section{Experimental birds}

A closed flock population of guinea fowl was reared at experimental guinea fowl farm of Central Avian Research Institute, Izatnagar. Each Guinea fowl keet was wing banded at the time of hatching for identification of pedigree. The keets were maintained separately on deep litter system in brooder houses up to the age of 5 weeks. Thereafter, they were shifted to grower and layer houses and reared under uniform husbandry conditions. All birds were offered ad libitum water and ration with a constant $14 \mathrm{hr}$ light per day throughout the experiment. The layers were used for production of Guinea fowl keets used in the current study.

\section{Peripheral blood mononuclear cells (PBMCs) culture}

Approximately $3 \mathrm{ml}$ of heparinized blood from individual bird was collected from Jugular vein under sterile conditions. Three milliliter of Histopaque-1077 (Sigma Diagnostics Inc., St. Louis, MO, USA) was added to $15 \mathrm{ml}$ conical centrifuge tube at room temperature and $3 \mathrm{ml}$ of whole blood was carefully layered over the column and centrifuged at $1700 \mathrm{rpm}(900 \mathrm{x} \mathrm{g})$ for $30 \mathrm{~min}$ at room temperature. After centrifugation, the opaque inter-phase containing mononuclear 
cells was carefully aspirated with a micropipette. The upper layer was discarded. The opaque inter-phase was carefully transferred to a clean centrifuge tube and equal volume of ice chilled DEPC treated isotonic PBS solution was added and mixed gently, then centrifuged at $3000 \mathrm{rpm}(1400 \mathrm{x}$ g) for 10 minutes. The supernatant was discarded and cell pellet was re-suspended in equal volume of ice chilled DEPC treated isotonic PBS solution and centrifuged in 3000 rpm $(1400 \mathrm{x} g)$ for 10 minutes. This step was repeated two times and the cell pellet suspended finally in $0.5 \mathrm{ml}$ of RPMI-1640 medium containing $10 \%$ FCS. Viability of these cells was assessed using trypan blue staining and the cells were counted in a hemocytometer and the concentration adjusted to $10^{6}$ cells per $\mathrm{ml}$ in RPMI-1640 medium (Sigma inc., USA). The PBMCs suspended in RPMI-1640 medium supplemented with $10 \%$ FCS, were plated in 6 well tissue culture plate (106 cells per well) and induced with $100 \mu$ l of $2 \%$ LPS solution (Sigma, CA). The Plate was incubated under $5 \% \mathrm{CO} 2$ tension in humidified atmosphere for two hour at $37^{\circ} \mathrm{C}$ in a $\mathrm{CO} 2$ incubator.

\section{Total RNA isolation and cDNA synthesis}

Induced PBMCs were harvested by low-speed centrifugation after $1 \mathrm{hr}$ induction period. Total RNA was isolated from harvested cells using the Trizol reagent (Invitrogen) according to manufacturer's instructions. Concentrations and purities of RNA preparations were determined spectrophotometrically (Nanodrop, Thermo Inc.) using absorbance at 260 and $280 \mathrm{~nm}$. The A260/A280 ratio of the samples was $>1.8$. To confirm the integrity of the RNA and assess possible DNA contamination, $4 \mu \mathrm{l}$ of total RNA sample was electrophoresed on agarose gel, containing formaldehyde (Sambrooket al., 1989) and visualized by ethidium bromide staining. Possible traces of genomic DNA were removed by treating $5 \mu \mathrm{g}$ of RNA sample with $5 \mathrm{U}$ of RNase-free DNase at $37{ }^{\circ} \mathrm{C}$ for $1 \mathrm{~h}$. DNase was subsequently inactivated by inoculation at 65 ${ }^{\circ} \mathrm{C}$ for $10 \mathrm{~min}$. DNase-treated total RNA sample $(3 \mu \mathrm{g})$ was reverse-transcribed using the RevertAid first strand cDNA synthesis kit (MBI Fermentas, Hanover, MD, USA) according to manufaturer's instructions. Negative controls were performed using all components, but without added reverse transcriptase. The resultant cDNA was stored frozen at $-20{ }^{\circ} \mathrm{C}$.

\section{PCR amplification of the iNOS cDNA fragment}

A fragment of coding region of iNOSgene was amplified usinga pair of gene specific primer designed on the basis of available chicken iNOS sequence. PCR amplification was carried out in $25 \mu \mathrm{l}$ volume containing 1X PCR buffer, 1.5 unit of Taq DNA polymerase, $1.5 \mathrm{mM} \mathrm{MgCl} 2,200 \mathrm{mM}$ dNTPs (Promega); 20 pmol of each pair of gene specific primers and $1 \mu \mathrm{l}$ of the reverse transcription product. Amplification was carried out in a thermal cycler (iCycler, BioRad, Hercules, CA) for 35 cycles with the following conditions: initial denaturation at $94{ }^{\circ} \mathrm{C}$ for $10 \mathrm{~min}$, denaturation at $94{ }^{\circ} \mathrm{C}$ for 30 sec, annealing at $56^{\circ} \mathrm{C}$ for $45 \mathrm{sec}$ and extension at $72{ }^{\circ} \mathrm{C}$ for $1 \mathrm{~min}$ and a final extension at $72{ }^{\circ} \mathrm{C}$ for $10 \mathrm{~min}$. The amplification products were separated on a $1.6 \%$ TBE agarose gel and visualized by ethidium bromide staining. The PCR products were purified from gel using QIAquick Gel Extraction Kit (QIAGEN Inc. Valencia, CA, USA).

\section{Cloning of the purified PCR products}

The gel purified PCR products were cloned into PGEM ${ }^{\circledR}$ Teasy (Promega, USA) cloning vector. The $100 \mathrm{ng}$ purified PCR product was 
ligated with T/A cloning vector plasmid using T4 DNA Ligase enzyme according to manufacturer's instructions. Freshly prepared competent $\mathrm{DH} 5 \alpha$ (E. coli) cells were transformed with the ligated DNA. The Transformed cells were then plated on LB/Amp/X-gal/IPTG plates and incubated overnight at $37^{\circ} \mathrm{C}$. The positive recombinant clones were identified from the transformed bacterial colonies using blue and white selection. Further, the presence of the insert was confirmed by restriction digestion with EcoRI and PCR amplification of insert using recombinant plasmid as a template.

\section{Sequence analysis}

The positive clones were sequenced commercially by automated sequencer using standard cycle conditions by Sanger's dideoxy chain termination method with standard sequencing primers (viz., T7 and SP6). Obtained sequence of iNOSgene (cDNA) was subjected to BLAST analysis (www.ncbi.nlm.nih.gov/Blast) to ascertain whether the obtained sequence was of iNOS. The nucleotide as well as deduced amino acid sequence of iNOS gene of guinea fowl was aligned with those of other avian species available in the GenBank database using Clustal method of MegAlign programme of Lasergene software (DNASTAR, USA).

\section{Results and Discussion}

A single and specific band of $\sim 792$ bp was amplified from the cDNA of guinea fowl using a pair of gene specific primer designed on the basis of available chicken iNOS sequence (Fig 1).

\section{iNOS gene sequence analysis}

The positive clones were sequenced using ABI Prism DNA sequencer at DNA Sequencing Facility, University of Delhi,
South Campus, New Delhi. Sequencing was done both the ways i.e. 5'-3' and 3'-5'. Sequencing confirmed the size of the amplified Gf-iNOS fragment to be 792 bp (GenBank Accession No. EU000565).

\section{Nucleotide sequence variation between guinea fowl and other poultry species}

The present Gf-iNOS partial CDS sequence was compared with the similar iNOS sequences reported in other poultry species. Total size of Gf-iNOS partial CDS fragment was $792 \mathrm{bp}$. This fragment is equivalent to the chicken iNOS in size and no insertion or deletion was observed. The other sequences from chicken and quails were smaller sequences.

Sizable polymorphism was observed between guinea fowl and other poultry species for iNOS nucleotide sequence. Between guinea fowl and quail, polymorphism at 16 nucleotide positions out of 371 nucleotide positions was observed, while between guinea fowl and chicken, 32 out of 792 nucleotides were polymorphic. The ratio between nonsynonymous to synonymous nucleotide substitutions was 1:4.6 between guinea fowl and chicken, whereas it was 1:4.3 between guinea fowl and quail.

\section{Amino acid sequence variation between guinea fowl and other poultry species}

The amino acid sequences were derived from the nucleotide sequence of iNOS of the guinea fowl as well as other poultry species and compared. The iNOS amino acid sequence comprised of 263 amino acids in guinea fowl. The comparable sequence from chicken also produced 263 aa, where as in quail, the available nucleotide sequence was partial and much smaller, hence produced only 123 amino acids. Out of 263 amino acids between guinea fowl and chicken, 7 (2.66 \%) 
were polymorphic, while out of 123 amino acids between guinea fowl and quail, 4 (3.25 $\%)$ were polymorphic.

\section{SNPs analysis in iNOS gene}

The nucleotide sequence alignment of GfiNOS gene with the iNOS genes from other poultry species identified 7 SNPs (Table 1). The positions of these SNPs were 320, 370, 409, 460, 484, 520 and 553 nts. The alleles at these positions were A, T, C, T, A, A and T in guinea fowl, while in other poultry species, respective alleles were $T, C, T, A, G, G$ and C. Malec et al., (2003) reported one SNP, a T/C substitution at position $173 \mathrm{bp}$ in their sequence (AF537190), in the intronic region. The identified SNPs in the present study may be used for identifying their association with any functional change in the iNOS expression in particular and overall disease resistance in general.

Table.1 Probable SNPs in iNOS sequence in guinea fowl

\begin{tabular}{|c|c|c|c|}
\hline Sl. No. & Nt position & Allele in guinea fowl & Allele in other specie \\
\hline 1 & 320 & A & T \\
\hline 2 & 370 & T & C \\
\hline 3 & 409 & C & T \\
\hline 4 & 460 & T & A \\
\hline 5 & 484 & A & G \\
\hline 6 & 520 & A & G \\
\hline 7 & 553 & T & C \\
\hline
\end{tabular}

Table.2 Restriction enzyme profiles of iNOS in different poultry species

\begin{tabular}{|l|c|c|c|}
\hline \multirow{2}{*}{ Enzyme } & \multicolumn{2}{|c|}{ Restriction enzyme site } \\
\cline { 2 - 4 } & \multicolumn{1}{|c|}{ Quail } & Chicken & Guinea Fowl \\
\hline Rsa I & & $94 \& 95$ & \\
\hline Mn II & $120 \& 121$ & & \\
\hline Hpa II & $128 \& 129$ & & $134 \& 135$ \\
\hline Nci I & $128 \& 129$ & & $134 \& 135$ \\
\hline Msp I & $128 \& 129$ & & $134 \& 135$ \\
\hline Mbo I & & & $136 \& 137$ \\
\hline Sau3A I & & $264 \& 265$ & \\
\hline Nde II & & $266 \& 267$ & \\
\hline Dpn I & & & \\
\hline Eco47 III & & & \\
\hline Hae II & & & \\
\hline Nsi I & $307 \& 308$ & & \\
\hline
\end{tabular}

Table.3 Percent identity between Guinea fowl and other poultry species based on sequence homology for iNOS gene

\begin{tabular}{|l|c|c|c|c|}
\hline & D85422-chk & EF178279-chk & NM 204961-chk & EU000565-GF \\
\hline DQ206459-quail & 96.7 & 97.0 & 97.0 & 95.7 \\
\hline D85422-chk & & 99.2 & 99.7 & 95.6 \\
\hline EF178279-chk & & & 100.0 & 96.2 \\
\hline NM 204961-chk & & & & 96.1 \\
\hline
\end{tabular}


Fig.1 Amplification of 792 bp Gf-iNOS (lane 1-3). M: 100 bp ladder

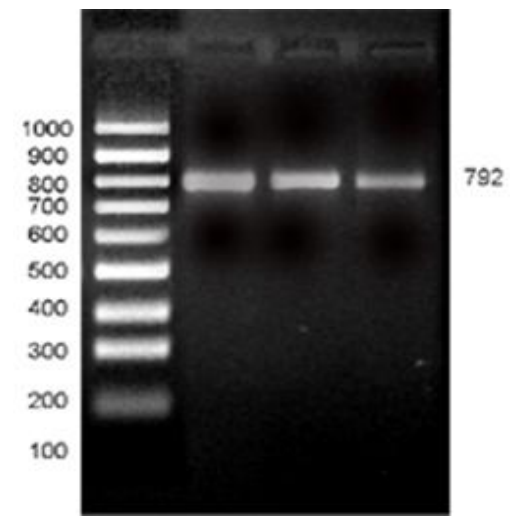

Fig.2 Phylogenetic tree for iNOS gene in different poultry species

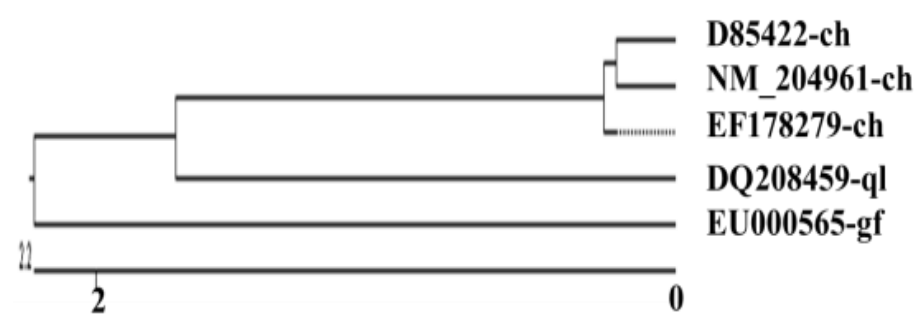

\section{Restriction enzyme mapping of iNOS gene}

The restriction enzyme map was developed for Gf-iNOS gene using Genetool software. For comparison, the restriction maps were also made for iNOS from other poultry species. The restriction enzyme maps were developed using 'commercial enzyme' option of GENETOOL software. By careful examination of these restriction maps, an array of restriction enzymes was identified to yield species specific restriction enzyme profile of iNOS in different poultry species (Table 2). In guinea fowl, 134 bp \& 658 bp fragments with $M b o$ I, 134 bp \& 658 bp fragments with Sau3A I, 134 bp \& 658 bp fragments with Nde II, 136 bp \& 656 bp fragments with $D p n$ I; in chicken, 94 bp \& 698 bp fragments with $R s a$ I, 264 bp \& 528 bp fragments with Eco47 III, 266 bp \& 526 bp fragments with Hae II; and in quail, 120 bp \& 251 bp fragments with $M n$ 1I, 128 bp \& 243 bp fragments with Hpa II, 128 bp \& 243 bp fragments with $N c i$ I, 128 bp \& 243 bp fragments with Msp I and 307 bp \& 64 bp fragments with $N s i$ I were expected after restriction digestions with respective enzymes.

\section{Genetic relatedness among guinea fowl and poultry species}

The sequence variation for iNOS gene in guinea fowl and other poultry species was used to estimate the per cent identity and divergence between them. Per cent identity between guinea fowl and poultry species on the basis of nucleotide sequence comparisons for iNOS gene is presented in Table 3.Based on nucleotide sequence comparisons for iNOS gene, guinea fowl showed very high and almost equal genetic identity (95.6 - 96.2) with chicken and quail. Quail and chicken also showed very high per cent identity (96.797.0) between them. 


\section{Phylogenetic analysis}

The phylogenetic tree (Fig. 2) placed all the chicken sequences in one cluster and quail and guinea fowl as separate branches. At the level of low divergence, quail seemed to be more close to chicken as compared to guinea fowl.

Prajapati et al., (2017) mentioned that the breeding for genetic resistance is one of the promising ways to control the infectious diseases. Further, Malek and Lamont, (2003) indicated that Identification of candidate genes to improve the immune response may be useful for marker-assisted selection to enhance disease resistance, the polymorphism identified in iNOS CDS in present study, may be utilized for exploring the mechanism of higher disease resistance in guinea fowl, which may further be exploited to develop disease resistant chicken population.

\section{Acknowledgement}

We gratefully acknowledge the ICAR, New Delhi and CARI, Izatnagar for providing the financial assistance and infrastructure supports to carry out the present study.We are highly thankful to late Dr. Deepak Sharma (Principal Scientist, CARI, Izatnagar) for his valuable guidance.

\section{References}

Bredt, D.S., Huang, P.M., Glatt, C.E., lownstein, C., Reed, R.R. and Snyder, S.H. 1991. Cloned and expressed nitric oxide synthase structurally resemble cytochrome P-450 reductase. Nature. 351: 713-718.

Charles, I.G., Palmer, R.M.J., Hickery, M.S., Bayliss, M.T., Chubb, A.P., Hall, V.S., Moss, D.W. and Moncada, S. 1993. Cloning, characterization, and expression of a cDNA encoding an inducible nitric oxide synthase from the human chondrocyte. Proc. Natl. Acad. Sci. USA. 90: 11419-11423.

Cho, H.J., Xie, Q.W., Calaycay, J., Mumford, R.A., Swiderek, K.M., Lee, T.D. and Nathan, C. 1992. Meat species identification by polymerase chain reaction-restriction fragment length polymorphism (PCR-RFLP) of mitochondrial 16S rRNA. J. Exp. Med. 176: 599-604.

De Groot, T. and Fang, B. 1995. Avian cytokines in health and disease. Rev. Bras.Cienc. Avi. 5 (1): 45-49.

Lamas, S., Marsden, P.A., Li, G.K., Tempst, P. and Michel, T. 1992. Differential cytokine expression in avian cells in response to invasion by Salmonella typhimurium. Proc. Natl. Acad. Sci. USA. 89: 6348-6352.

Liew, F.Y., Millott, S., Parkinson, C., Palmer, R.M. and Moncada, S. 1990. Macrophage killing of leishmania parasite in vivo is mediated by nitric oxide from L-arginine. J. Immunol. 144: 4794-4797.

Lin, A.W., Chang, C.C. and McCormick, C.C. 1996. Molecular cloning and expression of an avian macrophage nitric-oxide synthase cDNA and the analysis of the genomic 5-flanking region. J. Biol. Chem. 271 (20): 1191111919.

Lyons, C.R., Orloff, G.J. and Cunningham, J.M. 1992. Development of divergent lines for sheep RBC response in WLH chickens. J. Biol. Chem. 267: 63706374.

Malek, M. and Lamont, S.J. 2003. Association of INOS, TRAIL, TGF- $\beta 2$, TGF- $\beta 3$, and $\operatorname{IgL}$ genes with response to Salmonella enteritidis in poultry. Genet. Sel. Evol. 35 (Suppl. 1): S99-S111.

Marletta, M.A. 1993. Interferongamma/lipopolysaccharide-treated mouse embryonic fibroblasts are killed 
by a glycolysis/L-arginine-dependent process. J. Biol. Chem. 268: 1223112234.

Nathan, C. 1992. Nitric oxide as a secretory product of mammalian cells. FASEB $J$. 6: 3051

Prajapati, B.M., Gupta, J.P., Pandey, D.P., Parmar, G.A. and Chaudhari, J.D. 2017. Molecular markers for resistance against infectious diseases of economic importance. Vet World. 10(1): 112-120.

Sambrook, J.E., Fritschk, F. and Maniatis, T. 1989. Molecular cloning: a laboratory manual. 2nd ed., Cold spring Harbor
Laboratory Press, Cold Spring Harbor, N.Y. pp. 317-336.

Snyder, S.H. 1991. Cloned and expressed nitric oxide synthase structurally resemble cytochrome P-450 reductase. Nature. 351: 713-718.

Xie, Q.W., Cho, H.J., Calaycay, J., Mumford, R.A., Swiderek, K.M., Lee, T.D., Ding, A.H., Troso, T. and Nathan, C. 1992. Infectious bursal disease virus of chickens: pathogenesis and immunosuppression. Science. 256: 225228.

\section{How to cite this article:}

Goyal, G., R. K. S. Bais, V. Upmanyu, V. Agrawal, K. Shrman, A. K. Patil and Chatur, Y. A. 2021. Molecular Characterization and Sequence Analysis of iNOS Gene of Guinea Fowl (Numida meleagris). Int.J.Curr.Microbiol.App.Sci. 10(01): 3363-3370. doi: https://doi.org/10.20546/ijcmas.2021.1001.395 